\title{
Height growth, diameter increment and age relationship response to sustainable volume of subtropical Chir pine (Pinus roxburghii) forest of Karaker Barikot forest
}

\author{
Muhammad Sadiq khan ${ }^{1 *}$, Salman Khan ${ }^{1}$, Wisal Shah ${ }^{1}$, Ahmad Hussain \\ 2 and Shah Masaud ${ }^{3}$ \\ 1. Department of Environmental Sciences, University of Haripur, Pakistan \\ 2. Department of Forestry and Wildlife Management, University of Haripur, Pakistan \\ 3. Department of Agriculture Sciences, University of Haripur, Pakistan \\ *Corresponding author's email: Ksadiq259@gmail.com \\ Citation \\ Muhammad Sadiq khan, Salman Khan, Wisal Shah, Ahmad Hussain and Shah Masaud. Height growth, diameter \\ increment and age relationship response to sustainable volume of subtropical Chir pine (Pinus roxburghii) forest of \\ Karaker Barikot forest. Pure and Applied Biology. Vol. 5, Issue 4, pp760-767. \\ http://dx.doi.org/10.19045/bspab.2016.50095
}

Received: 24/02/2016 Revised: 15/07/2016

Accepted: 25/07/2016

Online First: 08/0082016

\section{Abstract}

This study was conducted in the Karaker Barikot forest of district Swat Pakistan to measure the relation of average tree height, diameter increment and age of Pinus roxburghii to the sustainable volume production. Total forest area was 724 hectares. Systematic sampling intensity $2.5 \%$ was used for the study area. Data was collected from 119 plots ( 1 plot= 0.1 hectare. The tree height $(\mathrm{m})$, diameter increment $(\mathrm{cm})$ and age (years) were measured using Spegial Relascope, Increment borer, and Diameter tape. The maximum tree height was estimated $23 \mathrm{~m}$ of 70 year age, and minimum $8.5 \mathrm{~m}$ of 13 year age. The maximum diameter increment was found $(5.4 \mathrm{~cm}$ for lower diameter classes $(12 \mathrm{~cm})$ and minimum for $2.2 \mathrm{~cm}$ of higher diameter classes $(64 \mathrm{~cm})$. The total average number of trees and volume were found $1314,1104 \mathrm{~m}^{3}$ respectively. The $\mathrm{R}^{2}$ values were $(.37, .98, .99$ of tree height, increment and age with diameter classes $(12-64 \mathrm{~cm})$ respectively. The $\mathrm{R}^{2}$ value (.988) was found significant for age and increment. It was concluded that there was significant relationship to the average age and height of Pinus roxburghii to the volume production. It was further concluded that the maximum growth increment significantly put the forest on the way to sustainability.

Keywords: Diameter increment; Increment borer; Spegial relascope; Sustainable

\section{Introduction}

Tree Diameter at Breast Height (DBH), tree height and tree density are the most important variables for forest inventory. It directly influences inventory attributes spatially the yield estimate and precision of tree growth of radiata pine $[1,2]$. Tree density has effect on both external and 
internal characteristics of trees within a tree stand by varying competition among trees for nutrients, water and solar radiation $[3,4]$. Forest Stocking direct link to diameter growth in many studies. Tree diameters were not related to forest density (620 to 12,000 stems per ha) in young $P$. radiata stand up to age 4 , however a minimum of diameter growth was observed with high density during the $5^{\text {th }}$ growth season [5]. The effect of density on the growth of height has been estimated to be low count than diameter growth [6], although several studies reported the increase of height to have great effect by high density [7]. Although in the field parameters of a single tree i.e. diameter and height can be measured directly in the field. Sustainability Criteria and indicators offer a comprehensive definition and operational quantification for such variables. A tool for forest management planning is the general forest growth model is still valid in the context of sustainable forest management [8]. Forest growth Models include a description of individual tree distributions (invariant height-diameter relation, simple mortality function that frequently leads to unrealistic estimates of stand structure [9]. Spatially explicit growth models offer a means for detailed stand structure estimation in a tree examination, stems are sections at different positions and rings are count from the crosscuts. The rings widths are measured and the height/age curves of the trunk were found out [10]. Comparison of height growth of young planted noble fir with the height growth estimates and concluded that the growth of young stand was high as compared to the predicted. It is famous by a numeral of European names, including Bloodwood, Kiaat, and Transvaal Teak. Native names in southern Africa was; Mninga, Mukwa,
Mulombwa, and Umbila. Many southern African countries it is necessary that harvest of $P$. angolensis trees having $35-40 \mathrm{~cm}$ diameter $(\mathrm{DBH})$, though this situation is generally unnoticed by unlicensed harvesters [11]. Diameters of deodar (Cedrus deodara) trees were measured at $1(30.48 \mathrm{~cm})$ interval aboveground level up to 7 feet (2.13 meters) and each set of diameters showed a strong linear correlation with diameter at breast height [12]. The average maximum height of the dominant species of these forests is $45-60 \mathrm{~m}$ for Abies pindrow and Cedrus deodara while 30 - $45 \mathrm{~m}$ for Pinus wallichiana [13]. The regression analysis between diameter and height was carried out it was pointed out that all the species have linear relationship with diameter $(\mathrm{cm})$ with different values of co-efficient of regression $\left(\mathrm{R}^{2}\right)$. The maximum average height showed by the dominant species (Fir, Kail, Deodar, and Chilgoza) of the study area to be 20.40, $16.06,12.24$ and $12.12 \mathrm{~m}$ respectively. Moreover the average maximum volume attained by the Kail, Fir, Deodar and Chalgoza trees was 1.92, 1.57, 0.46 and $0.291 \mathrm{~m} 3 \cdot$ tree- 1 respectively. The $\mathrm{R}^{2}$ value for the average height and diameter was .99, $.98, .89, .99[7]$.

\section{Material and methods \\ Study area}

Karaker forest is located at $34^{\circ} 36^{\prime} \mathrm{N}, 72^{\circ}$ $14^{\prime} \mathrm{E}$ and $34^{\circ} 38^{\prime} \mathrm{N}, 72^{\circ} 17^{\prime} \mathrm{E}$ coordinates, and elevation range from 800 to $1900 \mathrm{~m}$ from mean sea level. Present study was conducted in six compartments (724 ha) of Karaker Forest, Swat K.P. Detail map of the area is shown in Figure 1. 


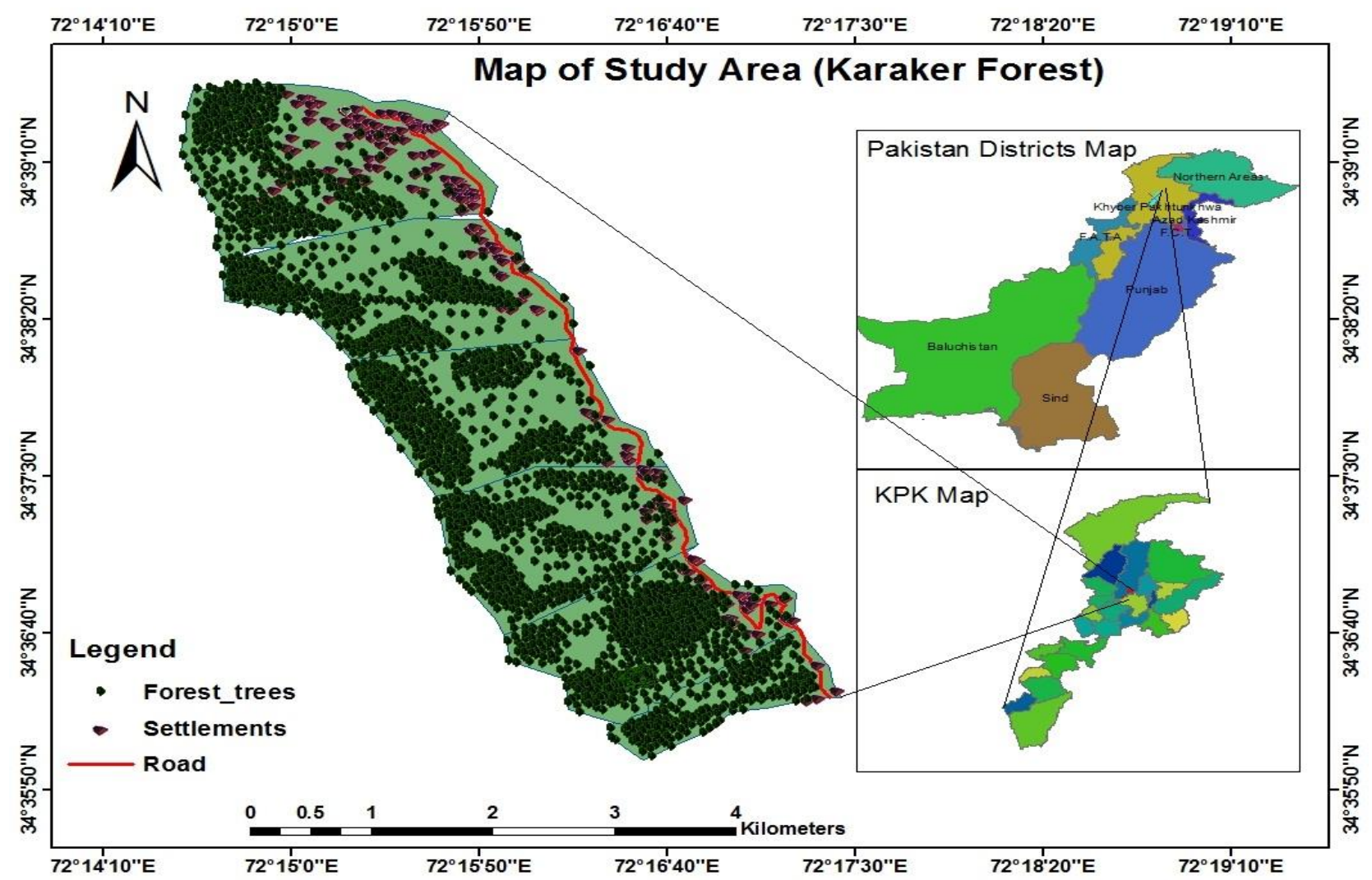

Figure 1. Map of the study area Karaker Barikot valley

\section{Method}

The study was conducted to estimate the tree height age, and diameter increment relation to diameter classes of Pinus roxburghii. 2.5 $\%$ sample intensity was used; total of 119 plots were taken in the study area using systematic method to equally distribute the plots in the study area to get unbiased data. The instruments Speigial relascope, increment borer, and diameter tap was used for data collection respectively. An instrument increment borer was used for the extraction of core from the standing tree and the last ten years rings were counted and measured to estimate the diameter increment and age of the tree. Speigial relascope was used for the diameter and height measurement of the trees. The data was analyzed among the diameter classes, diameter increment, height and age groups of the forest. The data was also statically analyzed through linear regression and correlation (Therrell et al., 2007) [14].

\section{Results and discussion}

\section{Diameter and height relationship}

The result found that the maximum tree height was $23 \mathrm{~m}$ of $56 \mathrm{~cm}$ diameter class and minimum of $8.5 \mathrm{~m}$ of the lower diameter class $12 \mathrm{~cm}$, total diameter classes ranges were $12-64 \mathrm{~cm}$. The statistical results were significant of $\mathrm{r}=.609$, and $\mathrm{R}^{2}=.37$ (fig.2). Similar study reported that the $A$. Pendrow, P. Williachina, C. Deodara and $P$. garardiana trees had height of 20.40, 16.06, 12.24 and $12.12 \mathrm{~m}$ respectively Raqeeb et al., (2014) [7]. The minimum average heights for all species were 2.42, 2.58, 3.03 and $3.33 \mathrm{~m}$ respectively. The value of $\mathrm{R}^{2}=.99$ indicate that the relationship between the diameter $(\mathrm{cm})$ and height $(\mathrm{m})$ was found significant. Sheikh (1993) [13] revealed that the height range of the dominant species were found 45 - $60 \mathrm{~m}$ for Fir and Deodar, 
while $30-45 \mathrm{~m}$ for Kail respectively. It was concluded that the tree diameter have a significant effect (Correlation was

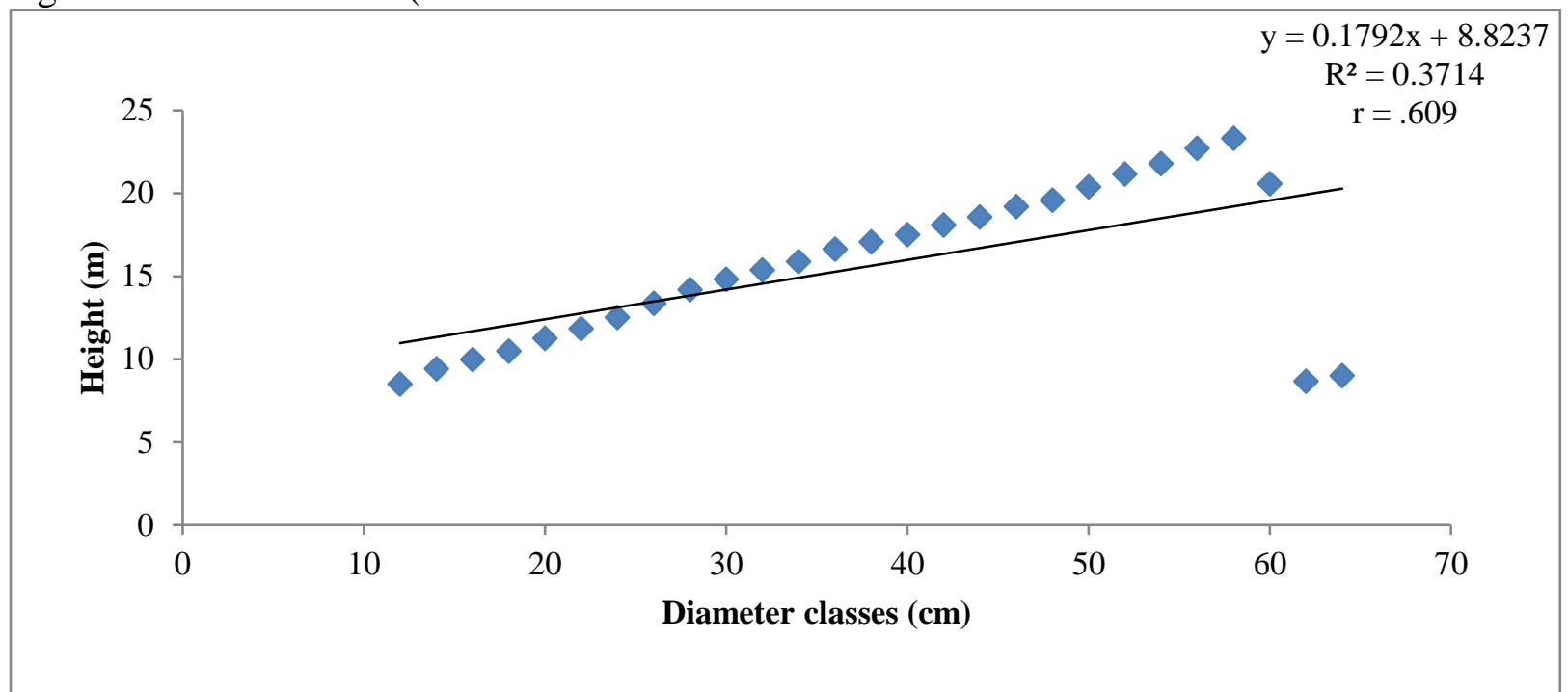

Figure 2. Relationship between Diameter classes and Height of the study area

Height and diameter increment relationship

The present study estimated that the maximum diameter increment was $5.4 \mathrm{~cm}$ at diameter class $12 \mathrm{~cm}$, and decreases as diameter increases and found minimum 2.25 $\mathrm{cm}$ at $64 \mathrm{~cm}$ diameter class, because with the increase in age, height and diameter the average increment decreases. The correlation and regression was $\mathrm{r}=-.997$, and $R^{2}=-.997$ found negative (fig. 3 ). The similar significant at the 0.01 level (2-tailed) on the tree height of the trees in the study area.

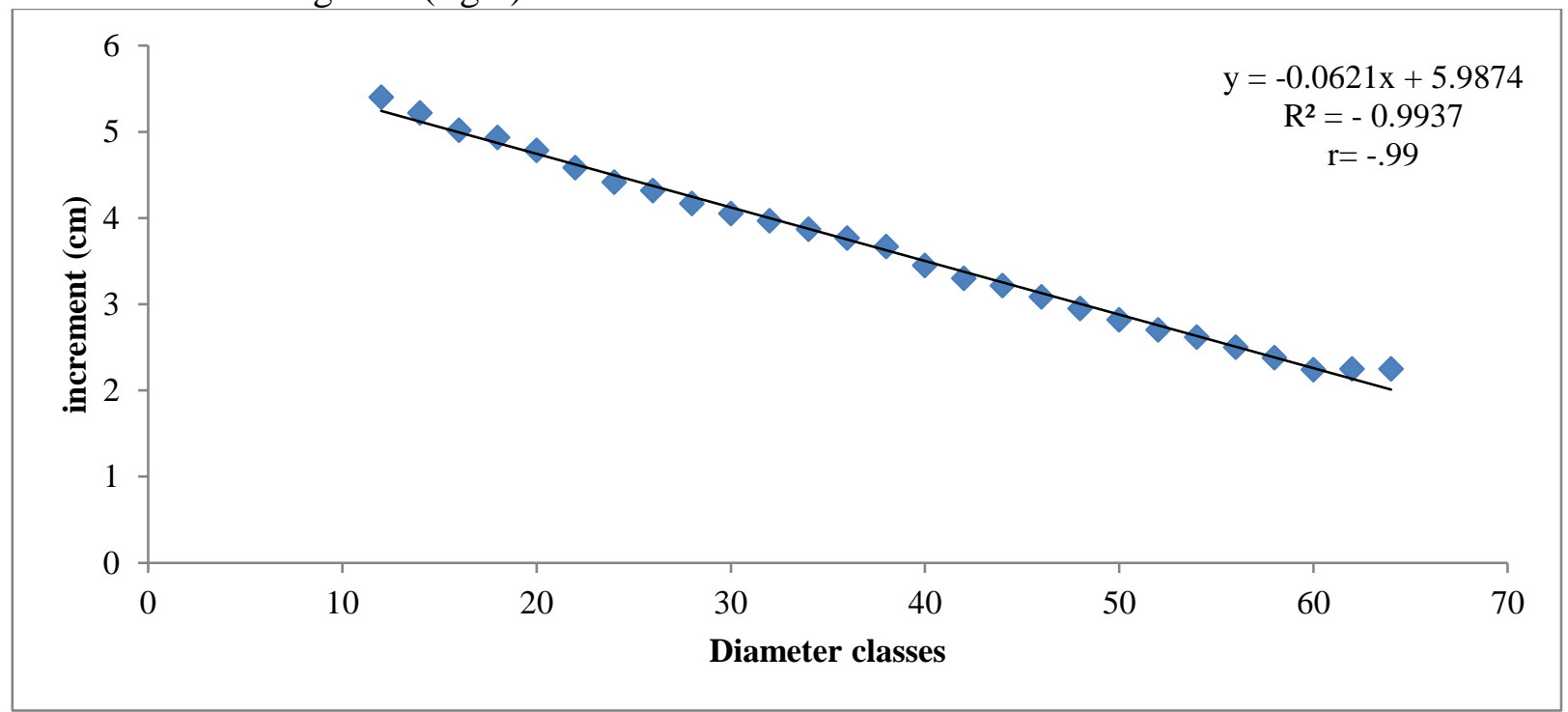

Figure 3. Relationship of diameter classes and mean increment of study area 


\section{Diameter and tree age relationship}

The research study found that there was strong relationship between diameter and age of the tree, the diameter have a direct proportion to the age of the stand. The lower diameter class $(12 \mathrm{~cm})$ has 13 years age and the high diameter class $(64 \mathrm{~cm})$ has 70 years age in the study area. The relation was statistically analyzed and found the value of $\mathrm{r}=.99$ (p>.01) and $\mathrm{R}^{2}=.99$ (fig.4). Similar study revealed that growth rates changing among individual trees in the nine study sites. The change in the total stem diameter
(TSD) at (100 yr) age, between the fast and slow growing trees, at study sites and found that a slight as $(10 \mathrm{~cm})$ at Sikumi to high as $(32 \mathrm{~cm})$ at Luampa River. Change in mean stem diameter at (100 years) age, at the local level, range from $(27-40 \mathrm{~cm})$ Soutpansberg at Mihozhe site (Vermeulen, 1990; [16] Shackleton, 2002) [11]. In comparison of the present study it was found that the tree diameter and tree age relation have significant (Correlation was significant at the 0.01 level (2-tailed) effect.

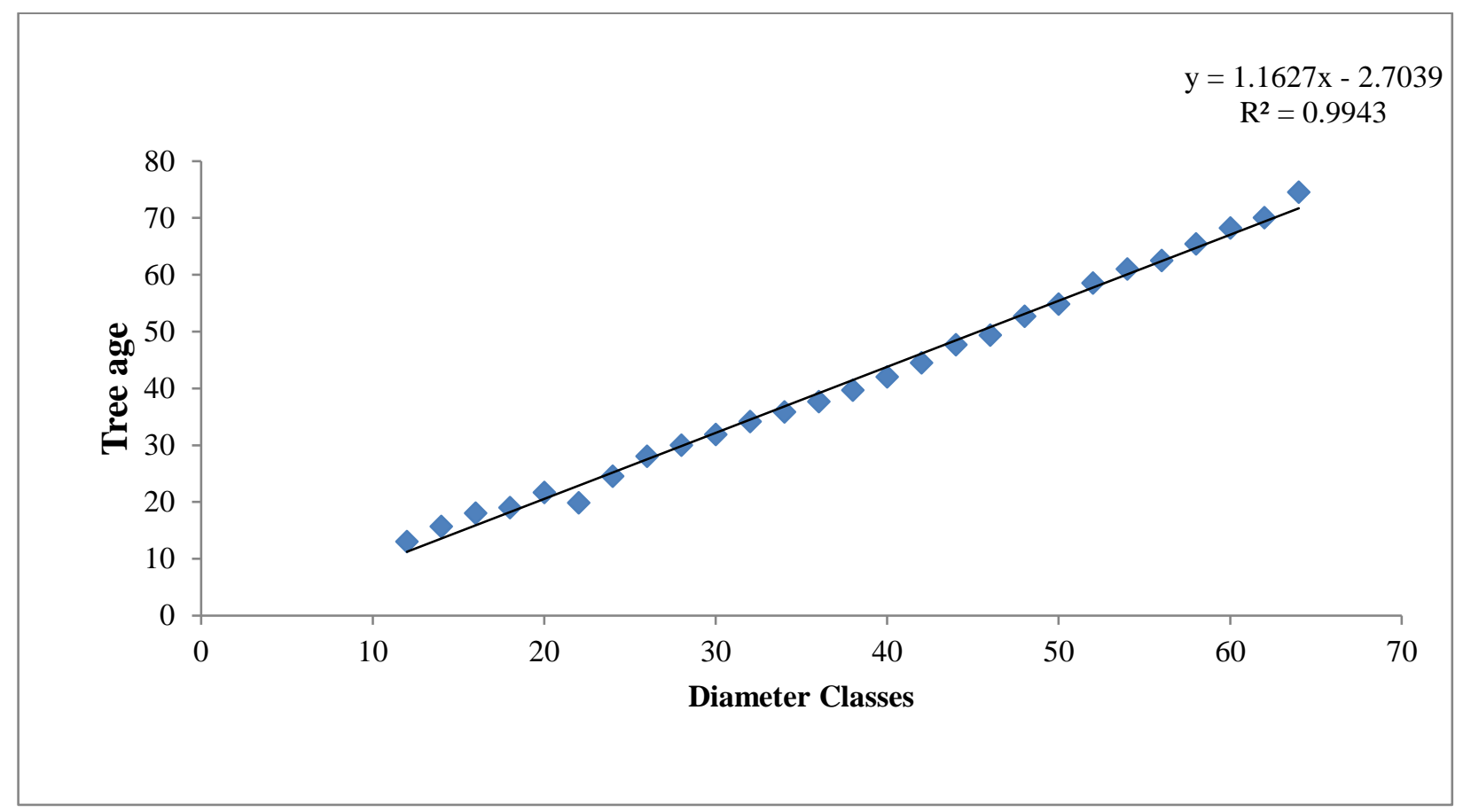

Figure 4. Relationship between the Diameter classes and tree age of the study area

\section{Relationship between tree height and age}

Present research study found the significant relationship of tree age and height, that tree age is best height predictor. Maximum tree age was 70 years for $23 \mathrm{~m}$ height. Height $(8.5 \mathrm{~m})$ was for 13 years age of Pinus roxburghii in the study area. The values of $\mathrm{r}$ $=.581$ and $\mathrm{R}^{2}=.338$ were found significant (fig.5). Similar study reported by Dennis et al., (2010) [17] that mean tree height (ft), 2.5 (min/max 0.5 to 22.9$)$ mean tree age (yr) at ground 8.5 , ( $\mathrm{min} / \max 3$ to 19 respectively). Results of many estimation of height and age relation, species in plots with respect to height by age by species was adopted to predict ages for future. Therefore, trees ages beyond $13 \mathrm{yr}$ were excluded from western larch, (14 yr) age for Douglas fir; (15 yr) age for ponderosa pine, and western white pine, and western red cedar; $16 \mathrm{yr}$ and $17 \mathrm{yr}$ respectively lodge pole pine $(17 \mathrm{yr})$ for Engelmann spruce and grand fir (18 yr) for 


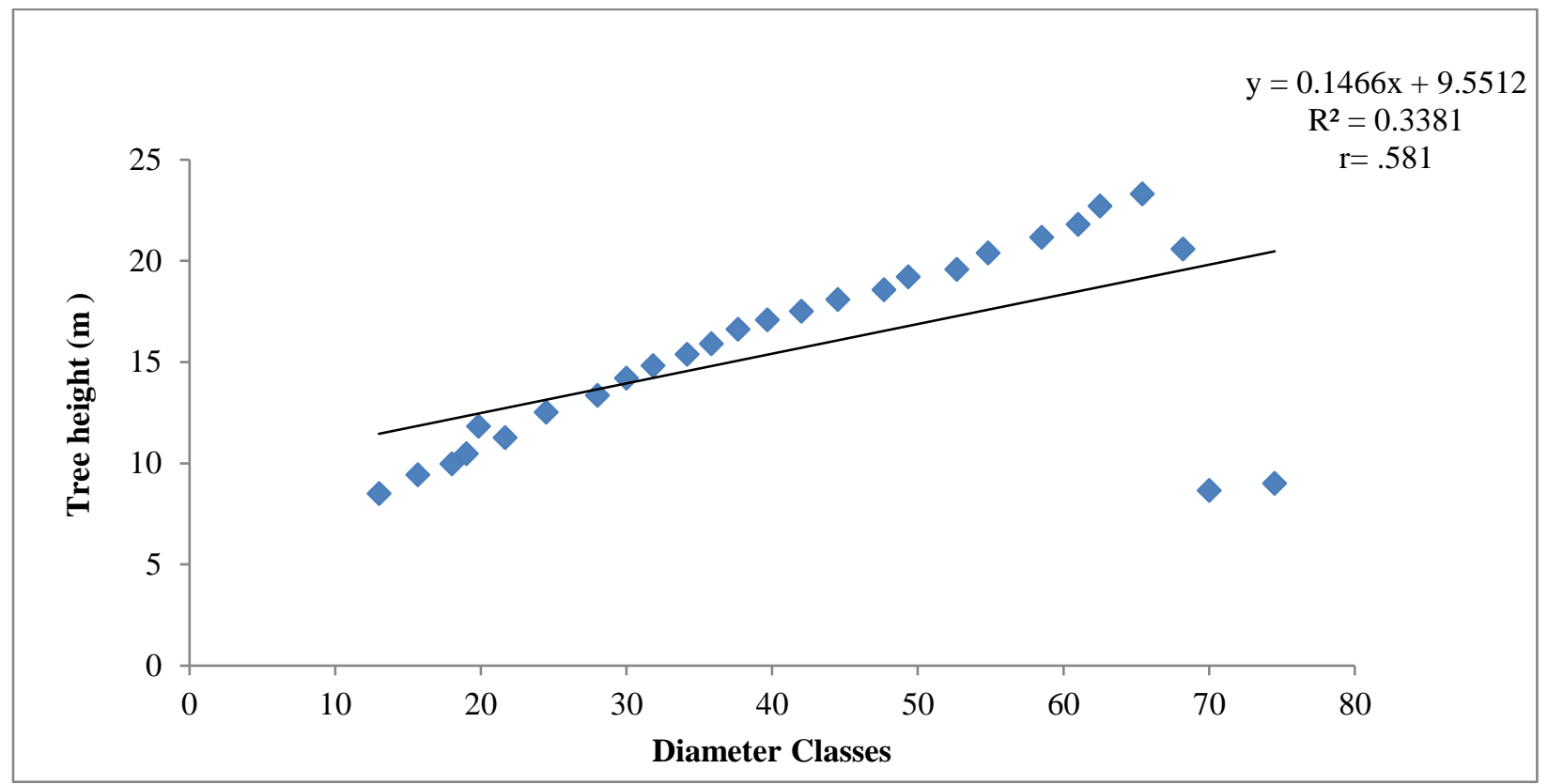

Figure 5. Relationship between tree height and tree age of the study area (Karaker forest)

Diameter, age and volume relationship The average diameter class range (12-64 $\mathrm{cm})$ and average ages (13-74 yrs) of the Karaker forest contribute to the average standing volume $1104 \mathrm{~m}^{3}$. The maximum volume was at higher diameter $(30-64 \mathrm{~cm})$ and age (31-74 yrs) range, and found 831 $\mathrm{m}^{3}$.the result of this study found that the age and height have a great contribution in average volume production as shown in (Fig $6)$.

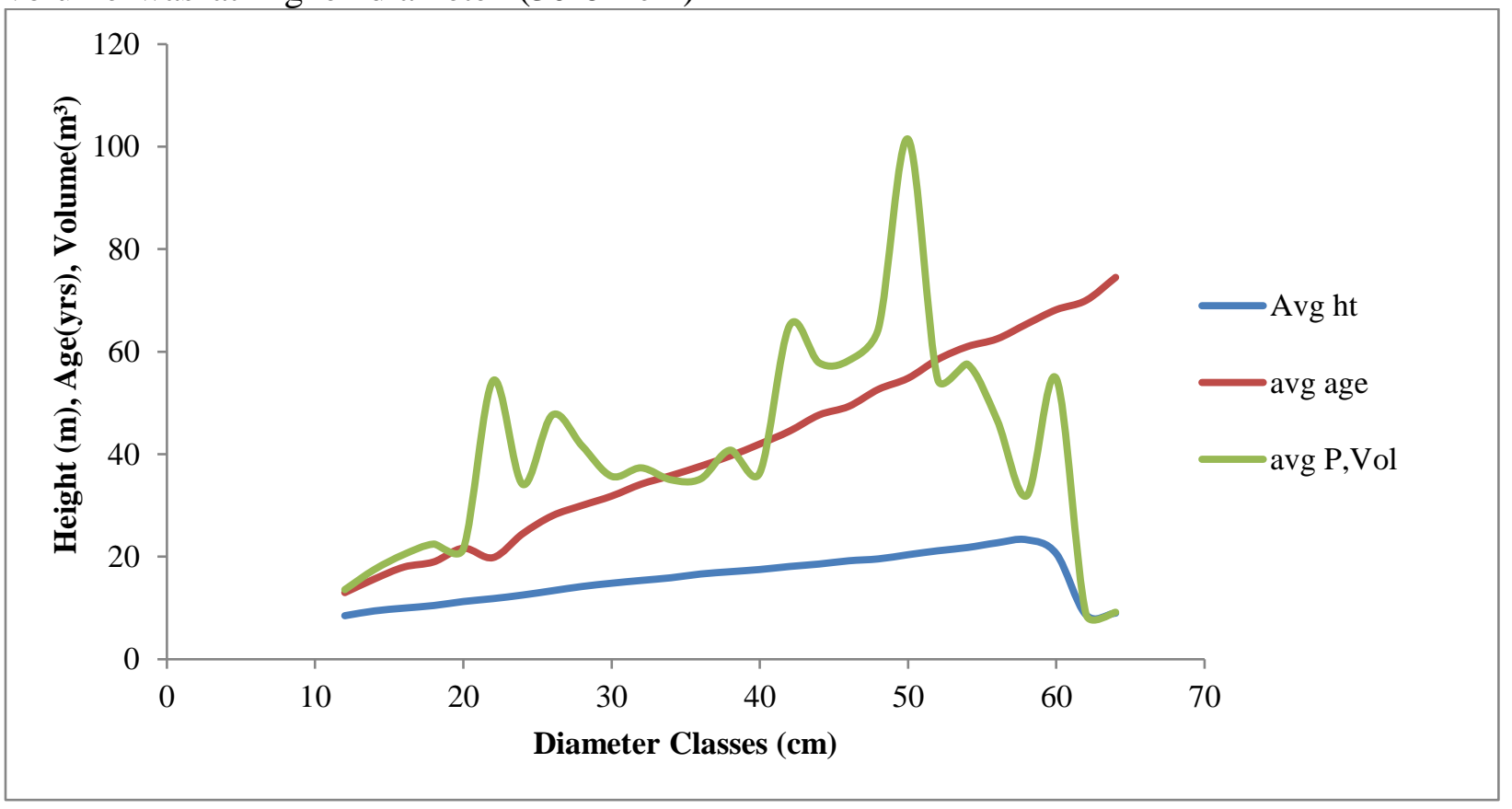

Figure 6. Relation between Diameter classes verses height, age and volume 


\section{Conclusion}

It has been concluded from the present study that forest growing stock parameters have significant role in the balancing the forest growth. Diameter increment has a significant relation with the height and age of the forest stand which have a direct effect on the volume production of the forest. It was statistically analyzed that these parameters have strong correlation with each other. The normal growth of these parameters put the forest towards sustainable volume production.

\section{Authors' contributions}

Conceived and designed the experiments: S Khan. Performed the experiments: Analyzed the data: S Khan, A Hussain, Contributed reagents/ materials/ analysis tools: S Khan \& A Naz, Wrote the paper: W Shah \& A Hussain.

\section{Acknowledgements}

We are thankful to the field staff of Swat Forest Division for their great support in the data collection for the study.

\section{References}

1. McCallum DJ, Mason EG and Whitley BNZ (2007). Influence of exposure and elevation on radiata pine branch size, log velocity, sweep, taper and value. J For Sci 52: 10-16.

2. Álvarez J, Allen HL, Albaugh TJ, Stape JL, Bullock BP \& Song C (2013). Factors influencing the growth of radiata pine plantations in chile. Forestry 86: 13-26.

3. Lasserre JP, Mason EG \& Watt M (2004). The influence of initial stocking on corewood stiffness in a clonal experiment of 11-year-old. Pinus radiata J For Sci 49: 18-23.

4. Carnwath GC, Peterson DW \& Nelson CR (2012). Effect of crown class and habitat type on climate-growth relationships of ponderosa pine and Douglas-fir.
5. Mason EG (1992). Decision-Support Systems for Establishing Radiata Pine Plantations in the Central North Island of New Zealand. Ph.D. Thesis, University of Canterbury, Christchurch, New Zealand, 1992.

6. Bortolot ZJ (2006). Using tree clusters to derive forest properties from small footprint lidar data. Photogramm. Eng. Remote Sens 72: 1389-1397.

7. Raqeeb A, Nizami SM, Saleem A \& Hanif M (2014). Characteristics and Growing Stocks Volume of Forest Stand in Dry Temperate Forest of Chilas Gilgit- BaltistanOpen Journal of Forests, 4:231-238. http://dx.doi.org/10.4236/ojf.2014.430 30

8. Monserud RA (2003). Evaluating forest models in a sustainable forest management context. For Biol Model Inf Sci. 1: 35-47

9. Landsberg J (2003). Modeling forest ecosystems: state of the art, challenges, and future directions. Can J For Res 33: 385-397.

10. Weiskittel AR, Hann DW, Kershaw Jr \& Vanclay JK (2011). Forest Growth and Yield. Modeling. John Wiley \& Sons Ltd., Chichester.

11. Shackleton CM (2002). Growth patterns of Pterocarpus angolensisin savannas of the South African lowveld. Forest Ecol Manage 166: 8597.

12. Chandra MS, Baduni NP, Gairola S, Ghildiyal SK \& Suyal S (2010). Tree Diversity and Carbon Stocks of Some Major Forest Types of Garhwal Himalaya, India. Forest Ecology \& Management 260: 2170-2179.

13. Sheikh MI (1993). Trees of Pakistan. Peshawar: Pakistan Forest Institute, p. 142.

14. Therrell MD, Stahle DW, Mukelabai MM \& Shugart HH (2007). Age, and 
radial growth dynamics of Pterocarpus angolensis in southern Africa. Forest Ecology and Management, 244 (1): 24-31.

15. Wonn HT \& Hara KL (2001). Height: diameter ratios and stability relationships for four northern Rocky Mountain tree species. Western Journal of Applied Forestry, 16(2): 8794

16. Vermeulen WJ (1990). A Monograph on Pterocarpus angolensis. SARCCUS
Standing Committee for Forestry, Pretoria, South Africa.

17. Dennis FE \& Carlson CE (2010). Height-age relationships for regeneration-size trees in the northern Rocky Mountains, USA. Res. Pap. RMRS-RP-82 WWW. Fort Collins, CO: U.S. Department of Agriculture, Forest Service, Rocky Mountain Research Station. Pp.19. 